\title{
Dopant-Dependent Electrical and Biological Functionality of PEDOT in Bioelectronics
}

\author{
Małgorzata Skorupa ${ }^{1,+}$, Daria Więcławska ${ }^{1,+}$, Dominika Czerwińska-Główka ${ }^{1} \mathbb{D}$, Magdalena Skonieczna ${ }^{2,3} \mathbb{D}$ \\ and Katarzyna Krukiewicz ${ }^{1, * \mathbb{D}}$
}

1 Department of Physical Chemistry and Technology of Polymers, Silesian University of Technology, 44-100 Gliwice, Poland; malgorzata.skorupa@polsl.pl (M.S.); daria.m.wieclawska@gmail.com (D.W.); dominika.czerwinska-glowka@polsl.pl (D.C.-G.)

2 Biotechnology Centre, Silesian University of Technology, 44-100 Gliwice, Poland; magdalena.skonieczna@polsl.pl

3 Department of Systems Biology and Engineering, Faculty of Automatic Control, Electronics and Computer Science, Silesian University of Technology, 44-100 Gliwice, Poland

* Correspondence: katarzyna.krukiewicz@polsl.pl; Tel.: +48-32-237-1312

+ These authors contributed equally to this work.

check for updates

Citation: Skorupa, M.; Więcławska,

D.; Czerwińska-Główka, D.;

Skonieczna, M.; Krukiewicz, K.

Dopant-Dependent Electrical and

Biological Functionality of PEDOT in Bioelectronics. Polymers 2021, 13, 1948. https://doi.org/10.3390/polym 13121948

Academic Editor:

Arunas Ramanavicius

Received: 14 May 2021

Accepted: 10 June 2021

Published: 11 June 2021

Publisher's Note: MDPI stays neutral with regard to jurisdictional claims in published maps and institutional affiliations.

Copyright: (c) 2021 by the authors. Licensee MDPI, Basel, Switzerland. This article is an open access article distributed under the terms and conditions of the Creative Commons Attribution (CC BY) license (https:// creativecommons.org/licenses/by/ $4.0 /)$.
Abstract: The aspiration to interact living cells with electronics challenges researchers to develop materials working at the interface of these two distinct environments. A successful interfacing coating should exhibit both biocompatibility and desired functionality of a bio-integrated device. Taking into account biodiversity, the tissue interface should be fine-tuned to the specific requirements of the bioelectronic systems. In this study, we pointed to electrochemical doping of conducting polymers as a strategy enabling the efficient manufacturing of interfacing platforms, in which features could be easily adjusted. Consequently, we fabricated conducting films based on a poly(3,4ethylenedioxythiophene) (PEDOT) matrix, with properties modulated through doping with selected ions: $\mathrm{PSS}^{-}$(poly(styrene sulfonate)), $\mathrm{ClO}_{4}{ }^{-}$(perchlorate), and $\mathrm{PF}_{6}{ }^{-}$(hexafluorophosphate). Striving to extend the knowledge on the relationships governing the dopant effect on PEDOT films, the samples were characterized in terms of their chemical, morphological, and electrochemical properties. To investigate the impact of the materials on attachment and growth of cells, rat neuroblastoma B35 cells were cultured on their surface and analyzed using scanning electron microscopy and biological assays. Eventually, it was shown that through the choice of a dopant and doping conditions, PEDOTbased materials can be efficiently tuned with diversified physicochemical properties. Therefore, our results proved electrochemical doping of PEDOT as a valuable strategy facilitating the development of promising tissue interfacing materials with characteristics tailored as required.

Keywords: bioelectronics; conducting polymer; doping; neural interface; PEDOT

\section{Introduction}

Electroactive interfacing of living cells constitutes the core of bioelectronic applications whose strategy is based on a cell-substrate communication. By this approach, striving to enable a controlled flow of information between the recipients, it is possible to interact electronics with a biological matter [1]. This concept is primarily employed in biomedical engineering purposes such as biosensors, tissue engineering, or neuroprosthetics [2], to allow for either sensing, stimulation, or control of biological communities on functional surfaces. The crucial role in a possibly seamless interconnection of those two distinct worlds of biotic and abiotic nature is played by the interfacing platforms, which need to fit several criteria. The materials of interest should be characterized by an ability to provide an electrical trigger to cells and should exhibit low impedance, suitable surface architecture, and biocompatibility [1]. Additionally, the growing variety of bioelectronic devices has been designed specifically for various cellular requirements, which in turn demands new advanced interfacing platforms adjusted to those particular needs. 
So far, numerous formulations have been studied for such purposes, however, there is still an ongoing effort towards achieving increased agility in the manufacturing of highperformance engineered surfaces. A great promise to create such tailorable interfacing platforms was shown by conducting polymers, which are believed to serve as next generation engineering materials particularly beneficial in the development of supercapacitors [3] and anticorrosion coatings [4]. In particular, poly(3,4-ethylenedioxythiophene) (PEDOT) draws considerable attention in providing electroactive coatings due to its high conductivity, high stability, and good biocompatibility, already shown for endothelial, epithelial, fibroblasts, macrophage, and human neural cell lines [5,6]. Recently, different forms of PEDOT were introduced as excellent biointerfaces, including organic platforms for neural stimulation and recording (PEDOT:Nafion) [7], hard tissue scaffolds (composite of PEDOT:PSS, gelatin and bioactive glass) [8], physiological strain sensors (composite of PEDOT:PSS functionalized CNTs and poly(glycerol sebacate urethane)) [9], and platforms for tissue engineering and organoid approaches (PEDOT:PSS crosslinked via glycidoxypropyltrimethoxysilane) [10].

However, another substantial reason for its attractiveness for bioelectronics, in addition to the palette of advantageous properties, is found in the ability to tune its physicochemical characteristics. Current strategies of modulating the behavior of PEDOT comprise the fabrication of composite structures with other conducting polymers, such as polyaniline [11], decoration of PEDOT surface with metallic particles [12], as well as electrosynthesis in the presence of various doping ions [13]. Essentially, doping leads to the modification of the electronic structure of polymers and influences their conductivity. This occurs by incorporating doping agents, which introduce charge carriers into the polymer chain and neutralize the unstable oxidized or reduced polymer backbone. Importantly, it is known that the dopant identity, namely its mobility and size, influences the features of conducting polymers and consequently has an impact on the interactions of cell-substrate systems [14]. Virtually, even trace amounts of introduced ions translate into markedly modified film properties, such as conductivity, ability to store electrical charge, biocompatibility, and morphology [13].

The selection of a doping agent appears to be a key factor in the design of diversified bioelectronic interfaces. However, there is still a disagreement regarding the understanding of actual relationships between the dopant character and the end-performance of a resultant coating. Baek et al. [15] demonstrated that doping with small ions results in the fabrication of PEDOT films, exhibiting increased surface roughness, lower impedance, and higher charge transfer capacity. The findings reported by Valle et al. [16] supported the relationship between the choice of a doping ion and polymer morphology, but were in contradiction to the previous reports when it comes to the conductivity: Valle claimed enhanced conductivity upon increasing ion size. Based on the above background and reported discrepancies, we considered it important to identify the exact correlation of dopant-film features and to leverage fluent fabrication of modulable polymeric interfaces.

In this work, we investigated three PEDOT-based materials obtained by incorporating different anionic dopants during the polymerization of EDOT. To meet the requirements of agile production, synthesis by electrochemical polymerization was employed, which permitted an efficient, easily controlled process yielding tailored products. As doping agents, PSS ${ }^{-}$(poly(styrenesulfonate)), $\mathrm{ClO}_{4}^{-}$(perchlorate), and $\mathrm{PF}_{6}^{-}$(hexafluorophosphate) were selected. To discuss how these different counterions affected morphological, biological, and electrical parameters of a PEDOT matrix, doped polymer films were investigated in terms of their conductivity, capacitance, chemical composition, surface morphology, and biocompatibility.

\section{Materials and Methods}

\subsection{Reagents}

3,4-ethylenedioxythiophene (EDOT), poly(sodium 4-styrenesulfonate) (NaPSS, average $\left.\mathrm{M}_{\mathrm{w}}=1,000,000 \mathrm{~g} / \mathrm{mol}\right)$, and tetrabutylammonium hexafluorophosphate $\left(\mathrm{nBu}_{4} \mathrm{NPF}_{6}\right)$ were obtained from Sigma Aldrich (Saint Louis, MO, USA). $\mathrm{nBu}_{4} \mathrm{NPF}_{6}$ was vacuum dried 
before use. Lithium perchlorate $\left(\mathrm{LiClO}_{4}\right)$ and potassium chloride $(\mathrm{KCl})$ were obtained from Acros Organics. Deionized water (Millipore quality) and acetonitrile (ACN, HPLC grade, Sigma Aldrich) were used as solvents.

\subsection{Electrochemical Polymerization}

The electrochemical polymerization of EDOT was performed by means of a $\mathrm{CH}$ Instruments, Inc. type 660C potentiostat (Austin, TX, USA) by a cyclic voltammetry (CV) scanning. A standard three-electrode setup was used, comprising a $\mathrm{Ag} / \mathrm{AgCl}(3 \mathrm{M} \mathrm{KCl})$ reference electrode (ET073, EDAQ, Denistone East, Australia), a platinum plate counterelectrode $\left(1 \mathrm{~cm}^{2}\right)$ (Mennica Polska, Warsaw, Poland), and a platinum plate working electrode $\left(0.283 \mathrm{~cm}^{2}\right)$ (Mennica Polska, Warsaw, Poland). The polymerization of EDOT (10 mM) was carried out in three different systems, consisting of different electrolyte salts and solvents, namely: NaPSS/water, $\mathrm{nBu}_{4} \mathrm{NPF}_{6} / \mathrm{ACN}$ and $\mathrm{LiClO}_{4} /$ water. The electrolyte concentration was $0.1 \mathrm{M}$ for both $\mathrm{nBu}_{4} \mathrm{NPF}_{6}$ and $\mathrm{LiClO}_{4}$, and for NaPSS it was calculated concerning a single structural unit $(0.1 \mathrm{M})$. In all cases, the scan rate was equal to $100 \mathrm{mV} / \mathrm{s}$ and the polymerization was conducted over $30 \mathrm{CV}$ cycles.

\subsection{Chemical and Morphological Characterization}

Morphological characterization was performed with a scanning electron microscope (SEM) Phenom ProX (Phenom-World BV, Eindhoven, The Netherlands) operating at $15 \mathrm{kV}$. Spectrochemical properties of investigated materials were analyzed using Raman spectroscopy (Renishaw inVia, Renishaw, Wotton under Edge, UK, $633 \mathrm{~nm}$ excitation laser) in the spectral range of $400-1600 \mathrm{~cm}^{-1}$.

\subsection{Electrochemical Characterization}

The electrochemical studies were performed by means of a potentiostat equipped with a three-electrode system mentioned earlier, in $0.1 \mathrm{M} \mathrm{KCl}$ aqueous solution. Cyclic voltammograms were collected over the potential range from $-0.4 \mathrm{~V}$ to $0.7 \mathrm{~V}$ (vs. $\mathrm{Ag} / \mathrm{AgCl}$ ) for five CV cycles with a scan rate of $100 \mathrm{mV} / \mathrm{s}$. Charge storage capacity (CSC) was calculated by integration of the area under the $\mathrm{CV}$ curve. Polymer voltammetric capacitance $\left(\mathrm{C}_{\mathrm{cv}}\right)$ was obtained by dividing the integrated area under theCV curve by two to obtain mean cathodic and anodic capacitance [17]. Electrochemical impedance spectroscopy (EIS) measurements were performed using $\mathrm{CH}$ Instruments, Inc. type $660 \mathrm{C}$ potentiostat (Austin, TX, USA), in $0.1 \mathrm{M} \mathrm{KCl}$ over frequencies ranging from $100 \mathrm{mHz}$ to $10 \mathrm{kHz}$, with an $\mathrm{AC}$ amplitude of $10 \mathrm{mV}$ and a DC potential of $0 \mathrm{~V}$ (vs. $\mathrm{Ag} / \mathrm{AgCl}$ ). The recorded spectra were fitted into an equivalent circuit by means of EIS Spectrum Analyser 1.0 [18] with the application of a Powell algorithm.

\subsection{In Vitro Biological Characterization}

Biological characterization was performed based on a rat neuroblastoma cell line B35 (CRL-2754 ${ }^{\mathrm{TM}}$, ATCC, Manassas, VA, USA). Cells were grown in a Dulbecco's Modified Eagle Medium/Nutrient Mixture F-12 (DMEM/F12, Sigma-Aldrich) supplemented with $10 \%$ fetal bovine serum (FBS, Gibco, Long Island, NY, USA) and gentamicin $(40 \mathrm{mg} / \mathrm{mL}$, Krka Poland Sp. z o.o., Warsaw, Poland) at $37^{\circ} \mathrm{C}$ in constant $80 \%$ humidity atmospheres and $5 \%$ carbon dioxide concentration (Heracell ${ }^{\mathrm{TM}}$ 150i, Thermo Scientific, Waltham, MA, USA). The cells were trypsinized with a $0.25 \%$ trypsin-EDTA solution (Sigma-Aldrich) in PBS, then neutralized by the addition of an equal amount of culture medium. Cells were seeded at $2 \times 10^{5}$ cells/well in $2 \mathrm{~mL}$ medium on 12-well plates (Biologix, Shandong, China) and were cultured for $48 \mathrm{~h}$. Subsequently, after the addition of $1 \mathrm{~mL}$ of $0.25 \%$ trypsinEDTA solution (Sigma-Aldrich) to each well, resulting cell suspensions were centrifuged at $1500 \mathrm{rpm}$ for $3 \mathrm{~min}$.

The cytotoxicity of reported materials was determined based on the ability of viable cells to reduce tetrazolium dye MTT (3-[4,5-dimethylthiazol-2-yl]- 2,5-diphenyltetrazolium bromide) to insoluble formazan. Consequently, $50 \mu \mathrm{L}$ of MTT solution $(0.05 \mathrm{mg} / \mathrm{mL}$ in 
phenol red and FBS free DMEM-F12; PAA) was added to samples collected from 12-well plates. After $1-2 \mathrm{~h}$ in a $\mathrm{CO}_{2}$ incubator, MTT solution was removed and the resulting formazan crystals were dissolved in $400 \mu \mathrm{L}$ acidic isopropanol. Absorbance measurements at $570 \mathrm{~nm}$ were performed using a multi-well plate reader SYNERGY4 (BioTek Instruments, New York, NY, USA).

The cell cycle of B35 neuroblastoma cells on PEDOT surfaces was analyzed by a flow cytometry (BD FACSAria ${ }^{\text {TM }}$ III, Becton, Dickinson and Company, Franklin Lakes, NJ, USA). Cells, after centrifugation, were washed with $500 \mu \mathrm{L}$ PBS and centrifuged again. Then, the cells were stained with $250 \mu \mathrm{L}$ of hypotonic buffer (comprised from PI $100 \mu \mathrm{g} / \mathrm{mL}$ in PBS; $5 \mathrm{mg} / \mathrm{L}$ of citric acid; 1:9 Triton-X solution; RNase $100 \mu \mathrm{g} / \mathrm{mL}$ in PBS from Sigma, Poznan, Poland) and DNA levels were assessed by fluorescence measurements at a PE configuration ( $547 \mathrm{~nm}$ excitation laser line; emission: $585 \mathrm{~nm}$ ).

The percentage of apoptotic and necrotic cells after $48 \mathrm{~h}$ of exposure on different samples was measured using FITC Annexin V Apoptosis Detection Kit with PI (Bio Legend, San Diego, CA, USA). Fifty microliters of Annexin V Binding Buffer, $2.5 \mu \mathrm{L}$ of FITC-conjugated Annexin $\mathrm{V}$ antibody, and $10 \mu \mathrm{L}$ propidium iodide $(100 \mu \mathrm{g} / \mathrm{mL})$ were added on each surface. Subsequently, the samples were vortexed gently and incubated in dark for $20 \mathrm{~min}$ at a room temperature $\left(25^{\circ} \mathrm{C}\right)$. Before measurements, $250 \mu \mathrm{L}$ of Annexin V Binding Buffer was added to each tube. Flow cytometric analysis enabled to determine the fluorescence of PI (necrotic cells) at the configuration for PE channel, and for AnnexinV FITC-conjugated antibody (apoptotic cells) at FITC channel configuration (488 $\mathrm{nm}$ excitation laser line; emission: LP mirror 503, BP filter 530/30).

The morphology of cells cultured on investigated surfaces was examined using SEM microscopy (Phenom ProX). B35 neuroblastoma cells were fixed using 3\% glutaraldehyde (Fisher BioReagents, Fair Lawn, NJ, USA) for $24 \mathrm{~h}$, then washed three times with deionized water. Samples were dehydrated by a $10 \mathrm{~min}$ immersion in the solutions of ethanol (Acros Organics, Morris Plains, NJ, USA) with increasing concentrations $(30 \%, 50 \%, 70 \%, 80 \%$, $90 \%, 95 \%$, and $99.8 \%$ ), and dried for $24 \mathrm{~h}$ at $50{ }^{\circ} \mathrm{C}$. Then, samples were sputter-coated with a gold layer (20 min, $20 \mathrm{~mA}$; Q150R Quorum Technologies, Laughton, UK), and SEM images were taken at $10 \mathrm{kV}$.

\section{Results}

\subsection{Electrochemical Polymerization}

As demonstrated in several previous studies [19], by choosing a doping agent, it is possible to affect the polymerization potential of the monomer, the efficiency of polymer formation, and its electrochemical characteristics. On that account, for each investigated system, the polymerization potential ranges were optimized separately. In all cases, the starting potential was chosen as $-0.8 \mathrm{~V}$ (vs. $\mathrm{Ag} / \mathrm{AgCl}$ ), which was associated with the lower limit of a water window for a bare platinum electrode. The oxidative potentials were selected based on the position of a polymerization peak (anodic peak responsible for irreversible oxidation of the monomer [20]) and its vicinity: onset potential ( $\left.E_{0}\right)$, the half-peak potential $\left(\mathrm{E}_{1 / 2}\right)$, the peak potential $\left(\mathrm{E}_{\mathrm{p}}\right)$, and the overoxidation potential $\left(\mathrm{E}_{\mathrm{oo}}\right)$, all approximated to $\pm 0.1 \mathrm{~V}$ (Figure $1 \mathrm{~A}-\mathrm{C}$ ). Upper potential limits for the polymerization of EDOT were optimized in terms of best electrical performance expressed by high CSC and low impedance at $1 \mathrm{kHz}$ (Figure 1D-F). Eventually, the anodic potentials of $1.8 \mathrm{~V}, 1.2 \mathrm{~V}$, and $1.2 \mathrm{~V}$ were chosen for $\mathrm{nBu}_{4} \mathrm{NPF}_{6} / \mathrm{ACN}, \mathrm{LiClO}_{4} / \mathrm{H}_{2} \mathrm{O}$, and $\mathrm{NaPSS} / \mathrm{H}_{2} \mathrm{O}$, respectively, and the corresponding polymerization curves of EDOT were plotted in Figure 1G-I. 

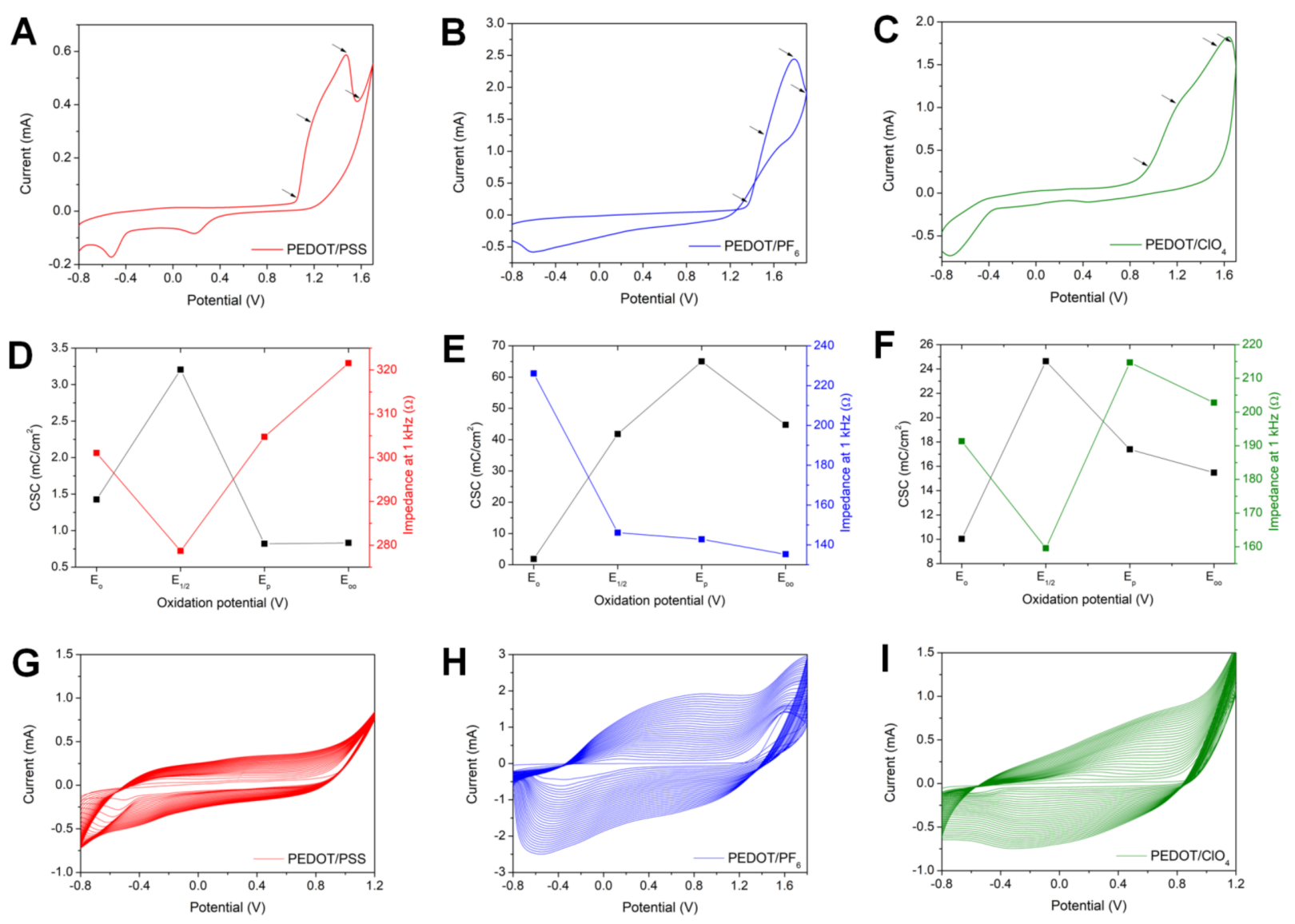

Figure 1. Optimization of electropolymerization conditions for each doping system (PEDOT/PSS, PEDOT/PF 6 , and PEDOT $\left./ \mathrm{ClO}_{4}\right)$. (A-C) CV curves showing the selection of oxidative potentials based on the position of a polymerization peak, where $E_{o}$ is the onset potential, $E_{1 / 2}$ is the half-peak potential, $E_{p}$ is the peak potential, and $E_{o o}$ is the overoxidation potential. (D-F) The variation of charge storage capacity (CSC) and impedance modulus at $1 \mathrm{kHz}$ with the choice of an oxidative potential. (G-I) CV curves showing the electropolymerization of EDOT under optimized conditions.

In each case, a typical, gradual increase in current density was observed in consecutive $\mathrm{CV}$ scans and was associated with the growth of a conducting polymer layer [21]. As easily observed from the magnitude of achieved currents, the efficiency of the polymerization process was dependent on the choice of a dopant/solvent system [21]. Among all investigated systems, the most prominent increase in current intensity was noted for PEDOT/PF This finding is consistent with literature reports stating that, generally, conducting polymer films formed in organic solvents are more conductive than those formed in aqueous solutions [22,23]. This is a result of a greater conjugation length of the polymer and more concise contact with the electrode surface [24] and may arise from different solubility of PEDOT oligomers in different solvents at the initial stages of polymerization [25]. The oligomers precipitate more readily in $\mathrm{ACN}$, attaching to the electrode surface and forming a high number of nucleation centers $[25,26]$. Another possible explanation for decreased efficiency of polymerization in aqueous solutions is attributed to the nucleophilic character of water molecules, which may lead to a competing reaction of water decomposition by interacting with initially formed polarons [25].

Unlike other conjugated polymers, the finite potential window of polythiophenes is difficult to observe because of the close proximity of the oxidative doping and oxidative degradation potentials [27]. Literature reports suggest that polythiophenes undergo overoxidation above the potentials of $1.45-1.55 \mathrm{~V}$ vs. SCE (1.48-1.58 V vs. Ag/ $\mathrm{AgCl}$ [28]), causing an irreversible damage to the conjugated system and impairing its electrical conductivity $[29,30]$. However, PEDOT polymerized in $\mathrm{nBu}_{4} \mathrm{NPF}_{6} / \mathrm{ACN}$ solution with a higher-end potential of $1.8 \mathrm{~V}$ (vs. $\mathrm{Ag} / \mathrm{AgCl}$ ) exhibited superior electrochemical properties among all 
tested potential ranges (Figure 1E). In this work, contrary to experiments demonstrating overoxidation of PEDOT [27,31], the electropolymerization was carried out in the presence of an excess of EDOT in the reaction solution. Therefore, at the anodic potential of $1.8 \mathrm{~V}$ (vs. $\mathrm{Ag} / \mathrm{AgCl}$ ), the oxidation of monomer might occur preferentially over the polymer degradation, leading to the formation of a polymer, exhibiting superior electrochemical properties. The deposition potentials optimized for the remaining two systems were in line with previously reported experiments, namely $1.2 \mathrm{~V}$ for both $\mathrm{LiClO}_{4} / \mathrm{H}_{2} \mathrm{O}$ [19] and $\mathrm{NaPSS} / \mathrm{H}_{2} \mathrm{O}$ [32].

\subsection{Surface Characterization}

It is well known that the polymerization conditions, such as potential range and the choice of a solvent and doping ion, greatly influence not only the conductivity of the matrix but also its surface morphology [19]. Moreover, these characteristics are directly related, as an increase in surface area translates into lowering of impedance [33]. This was also observed for PEDOT grown under investigated conditions (Figure 2A-C). PEDOT/PF 6 exhibited a highly developed, porous surface with micro- and nano-sized pores, resembling a sponge composed of interconnected chains. The surface of PEDOT/ $/ \mathrm{ClO}_{4}$ was more compact, displaying distinct, globular grains of varying sizes (3-11 $\mu \mathrm{m}$ in diameter with an average of $5.88 \pm 1.85 \mu \mathrm{m}$ ). Similar observations for $\mathrm{PF}_{6}{ }^{-}$and $\mathrm{ClO}_{4}{ }^{-}$doped PEDOT matrices were previously made by Culebras et al. [34]. On the other hand, the surface of PEDOT/PSS was identified as nonuniform, with numerous smaller and larger cavities revealing platinum surface. Also, when PEDOT/PSS surface was scanned by a highly energetic electron probe $(15 \mathrm{kV})$, the polymer film underwent degradation and multiple cracks were observed with the naked eye. Suffering from poor durability, PEDOT/PSS was found to be the least stable polymer compared to other investigated samples, which did not exhibit degradation after SEM exposure.
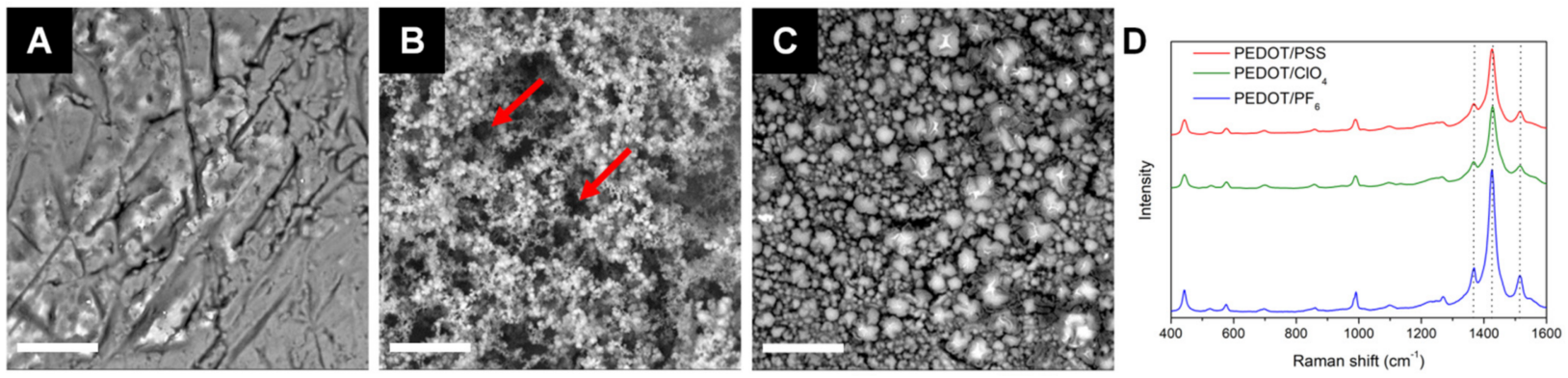

Figure 2. Surface characterization. SEM images obtained at $15 \mathrm{kV}$ for (A) PEDOT/PSS, (B) PEDOT/PF 6 , and $(\mathbf{C})$ PEDOT $/ \mathrm{ClO}_{4}$; scale bar represents $30 \mu \mathrm{m}$. Red arrows indicate pores in the polymer structure. (D) Raman spectra of the polymer coatings collected over the range of $400-1600 \mathrm{~cm}^{-1}$.

Generally, our results correlated with earlier research stating that the porosity is more enhanced with the decrease in the size of the doping ion [15]. It was confirmed that grainy, developed film architectures are typical for small dopants, such as $\mathrm{ClO}_{4}{ }^{-}$or $\mathrm{PF}_{6}{ }^{-}$ ions [19,34], whereas more compact structures are typical for large polymeric dopants like PSS [35]. Although ion size difference is negligible between $\mathrm{PF}_{6}{ }^{-}\left(2.42 \AA\right.$ [36]) and $\mathrm{ClO}_{4}{ }^{-}$ $(2.25 \AA[36])$, the surface is more porous upon doping with $\mathrm{PF}_{6}{ }^{-}\left(\mathrm{S}_{\mathrm{a}}=2.07 \mu \mathrm{m}\right)$ than $\mathrm{ClO}_{4}{ }^{-}$ ions $\left(\mathrm{S}_{\mathrm{a}}=1.79 \mu \mathrm{m}\right)$. This should be, however, associated with the effect of solvent, because according to multiple previous reports, the choice of solvent has a stronger influence on the morphology than the electrolyte [26,37]. For example, Seki et al. [25] indicated that water molecules may form hydrogen bonds with the conducting polymer, thus hindering its formation.

Surface morphology directly affects cellular adhesion. Rough topologies of conducting polymers were found to provide more suitable interfaces for cell attachment, compared to smooth metallic surfaces, conventionally applied as neural interfaces $[21,38]$. Nevertheless, 
other studies reported that the roughness factor is not decisive itself, but a crucial role is played by a correlation of cell size with the size of topographical details [34,39]. Comparable sizes occur to be favorable because a higher area of contact provides stronger and more stable attachment of cells or biofilm to the substrate [40]. Consequently, depending on the required application, surfaces should be individually examined for each cell type. For typical human neurons, the diameter of cell bodies is $10-50 \mu \mathrm{m}$ and the diameter of axons lies within the range of $1-25 \mu \mathrm{m}$, whereas the neurites can measure as small as a fraction of a micrometer [41]. The somas of B35 neuroblastoma cells used in this study are approximately $10 \mu \mathrm{m}$ in diameter. While the polymer architecture might not be ideally compatible with the cell body size, the cavities formed between the distinct polymer structures could offer better integration with axonal connections than a completely flat platinum surface.

The effect of dopant nature on structural properties of PEDOT samples was investigated by Raman spectroscopy (Figure 2D). In general, the acquired spectra of PEDOT doped with different counterions were similar to each other, and to those reported previously $[34,42,43]$, indicating that the chemical nature of PEDOT was maintained. Particularly, the most intensive bands located at $1515 \mathrm{~cm}^{-1}, 1426 \mathrm{~cm}^{-1}$, and $1366 \mathrm{~cm}^{-1}$ corresponded to asymmetric $C_{\alpha}=C_{\beta}$ stretching, symmetric $C_{\alpha}=C_{\beta}$ stretching, and $C_{\beta}-C_{\beta}$ stretching, respectively. The band at $1266 \mathrm{~cm}^{-1}$ originated from stretching modes of $C_{\alpha}-C_{\alpha}$ (interring); $\mathrm{C}-\mathrm{O}-\mathrm{C}$ deformation appears at $1096 \mathrm{~cm}^{-1}$. The modes at $990 \mathrm{~cm}^{-1}, 575 \mathrm{~cm}^{-1}$, and $442 \mathrm{~cm}^{-1}$ were ascribed to the oxyethylene ring deformation. The band at $698 \mathrm{~cm}^{-1}$ was related to symmetric deformation modes of $\mathrm{C}-\mathrm{S}-\mathrm{C}$.

\subsection{Electrochemical Characterization}

To compare electrochemical properties of PEDOT matrices, their CV curves were collected in a monomer-free $0.1 \mathrm{M} \mathrm{KCl}$ aqueous solution in the same potential range corresponding to the redox activity of PEDOT [19]. CV curves of all investigated coatings (Figure $3 \mathrm{~A}$ ) were of a rectangular shape, suggesting their largely capacitive character [1]. The most developed shape of a CV curve was exhibited by PEDOT/ $\mathrm{PF}_{6}$, followed by PEDOT $/ \mathrm{ClO}_{4}$ and PEDOT/PSS, respectively. All three polymers largely outperformed a bare platinum electrode, for which the CV curve resembled a flat line. To quantitatively compare the ability of PEDOT matrices to store electric charge, a charge storage capacity (CSC) was calculated from corresponding CV curves. CSC is a parameter applied frequently to compare the performance of bioelectronic interfaces [44]. In general, high values of CSC are desired, since they allow for using lower potentials to obtain a high current response. As presented in Figure 3B, the highest value of CSC $\left(80.1 \pm 6.3 \mathrm{mC} / \mathrm{cm}^{2}\right)$ was noted for PEDOT $/ \mathrm{PF}_{6}$, outperforming greatly both $\mathrm{PEDOT} / \mathrm{ClO}_{4}$ (CSC of $36.6 \pm 1.8 \mathrm{mC} / \mathrm{cm}^{2}$ ) and PEDOT/PSS (CSC of $18.4 \pm 1.23 \mathrm{mC} / \mathrm{cm}^{2}$ ), as well as a bare Pt electrode $\left(1.5 \pm 0.2 \mathrm{mC} / \mathrm{cm}^{2}\right)$.

Aurian-Blajeni et al. [33] showed that CSC is controlled by surface morphology. High effective surface area (surface to area ratio) allows for a larger part of the coating surface to be directly in contact with the solution, therefore enabling an increased charge transfer between the solution and the electrode coating. This correlation was also apparent in this work, with highly porous $\mathrm{PEDOT} / \mathrm{PF}_{6}$ exhibiting the greatest value of CSC. Interestingly, it is PEDOT/PSS with a typical CSC of $10-26 \mathrm{mC} / \mathrm{cm}^{2}$ [45-47] that is a formulation often used in various bioelectronic applications [48]. Although a CSC value determined in this study was in the typical range for PEDOT/PSS $\left(18.4 \pm 1.3 \mathrm{mC} / \mathrm{cm}^{2}\right)$, still, this material was found as the least capacitive among investigated PEDOT matrices. The relatively poor capacitance of PEDOT/PSS was related to the polymeric nature of PSS and, therefore, increased spacing between PEDOT chains [15], making the interchain hopping of electrons more difficult than in the case of small doping ions. 

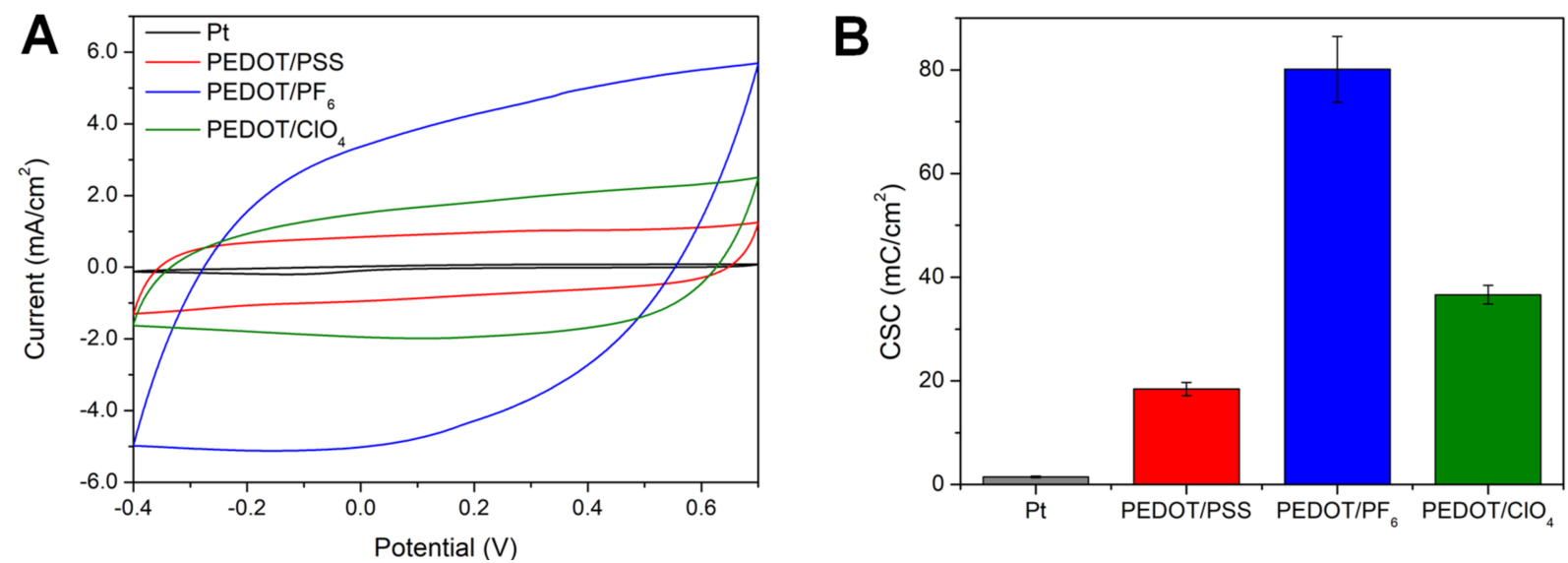

Figure 3. Cyclic voltammetric characterization of PEDOT matrices. (A) CV curves collected in $0.1 \mathrm{M} \mathrm{KCl}$ at a scan rate of $100 \mathrm{mV} / \mathrm{s}$; (B) Comparison of CSC values calculated from the CV data for a bare platinum electrode as well as the electrodes coated with PEDOT/PSS, PEDOT/PF 6 , and PEDOT/ClO $; n=3$.

Impedance is a crucial factor in bioelectronic considerations, as low impedance is necessary for enhancing charge transfer between the electrode and surrounding tissue. Low impedance profile is also responsible for maintaining a high signal to noise ratio in neural recording [49]. Usually, impedance behavior of electrodes is expressed as a magnitude of impedance modulus $(|\mathrm{Z}|)$. A relevant benchmark value used for comparing materials for bioelectronic applications, especially for neural electrodes, is $|\mathrm{Z}|$ measured at the frequency of $1 \mathrm{kHz}[50,51]$, which is the frequency associated with a neuron firing. Bode plots presenting the impedance module as a function of frequency (Figure $4 \mathrm{~A}$ ) revealed a similar level of $|\mathrm{Z}|$ at $1 \mathrm{kHz}$ for all investigated polymer samples (Figure $4 \mathrm{C}$ ), with a small prevalence of PEDOT $/ \mathrm{PF}_{6}(113.8 \pm 0.5 \Omega)$. The analysis of phase angle vs. frequency plots (Figure 4B) demonstrated notable variations in the phase angle, particularly at low frequencies, suggesting distinct capacitance of the studied PEDOT films.

To assess the resistance and capacitance of PEDOT films, EIS experimental data were fitted with the use of a Powell algorithm to an equivalent circuit model. As the most relevant, the modified Randles circuit was used, consisting of solution resistance $\left(R_{s}\right)$, charge transfer resistance $\left(\mathrm{R}_{\mathrm{ct}}\right)$, double-layer capacitance $\left(\mathrm{C}_{\mathrm{dl}}\right)$, Warburg diffusion element $\left(\mathrm{Z}_{\mathrm{W}}\right)$, and polymer bulk redox capacitance $\left(\mathrm{C}_{\mathrm{d}}\right)$. The presence of the latter was suggested by the shape of a Nyquist plot, and a necessity to simulate an element accounting for the phase angle shift from $45^{\circ}$ to $90^{\circ}$. Such a model was previously proposed by Danielsson et al. [52] for describing the behavior of PEDOT electrosynthesized in ionic liquids and was used by Kim et al. [53] to characterize PEDOT doped with polydopamine. EIS data exhibited sufficient goodness of fit $\left(\chi^{2}\right.$ values below 0.001$)$, proving a suitable choice of an equivalent circuit. The fitted spectra, together with experimental data, were presented in Figure 4A,B.

The electronic capacitive character of the polymer coating is represented by a capacitor element $C_{d}$ in the equivalent circuit. The highest capacitance concerning the electrode surface was obtained for PEDOT $/ \mathrm{PF}_{6}\left(47.6 \pm 7.1 \mathrm{mF} / \mathrm{cm}^{2}\right)$, which was three times greater than $\mathrm{C}_{\mathrm{d}}$ of PEDOT $/ \mathrm{ClO}_{4}\left(15.0 \pm 0.8 \mathrm{mF} / \mathrm{cm}^{2}\right)$ and six times greater than $\mathrm{C}_{\mathrm{d}}$ of PEDOT/PSS $\left(7.0 \pm 0.7 \mathrm{mF} / \mathrm{cm}^{2}\right)$. For comparison, the aerial capacitance of a PEDOT/PSS coating, prepared from chemically synthesized dispersions, is typically of approx. $1 \mathrm{mF} / \mathrm{cm}^{2}[54,55]$. The capacitance value achieved by $\mathrm{PEDOT} / \mathrm{PF}_{6}$ should be considered as impressive, since the aerial (interface) capacitance of supercapacitors determined basing on $\mathrm{CV}$ curves recorded at the same scan rate $(100 \mathrm{mV} / \mathrm{s})$ is usually of a similar order of magnitude (e.g., $75 \mathrm{mF} / \mathrm{cm}^{2}$ as noted for $\mathrm{NiCo}_{2} \mathrm{O}_{4}$ thin films [56]). Because of the lack of distinctive redox signals in CV curves of all PEDOT formulations, they should be considered as intrinsic pseudocapacitors, i.e., those in which the charge is mainly stored within an electric double layer rather than through faradaic redox reactions [57]. 

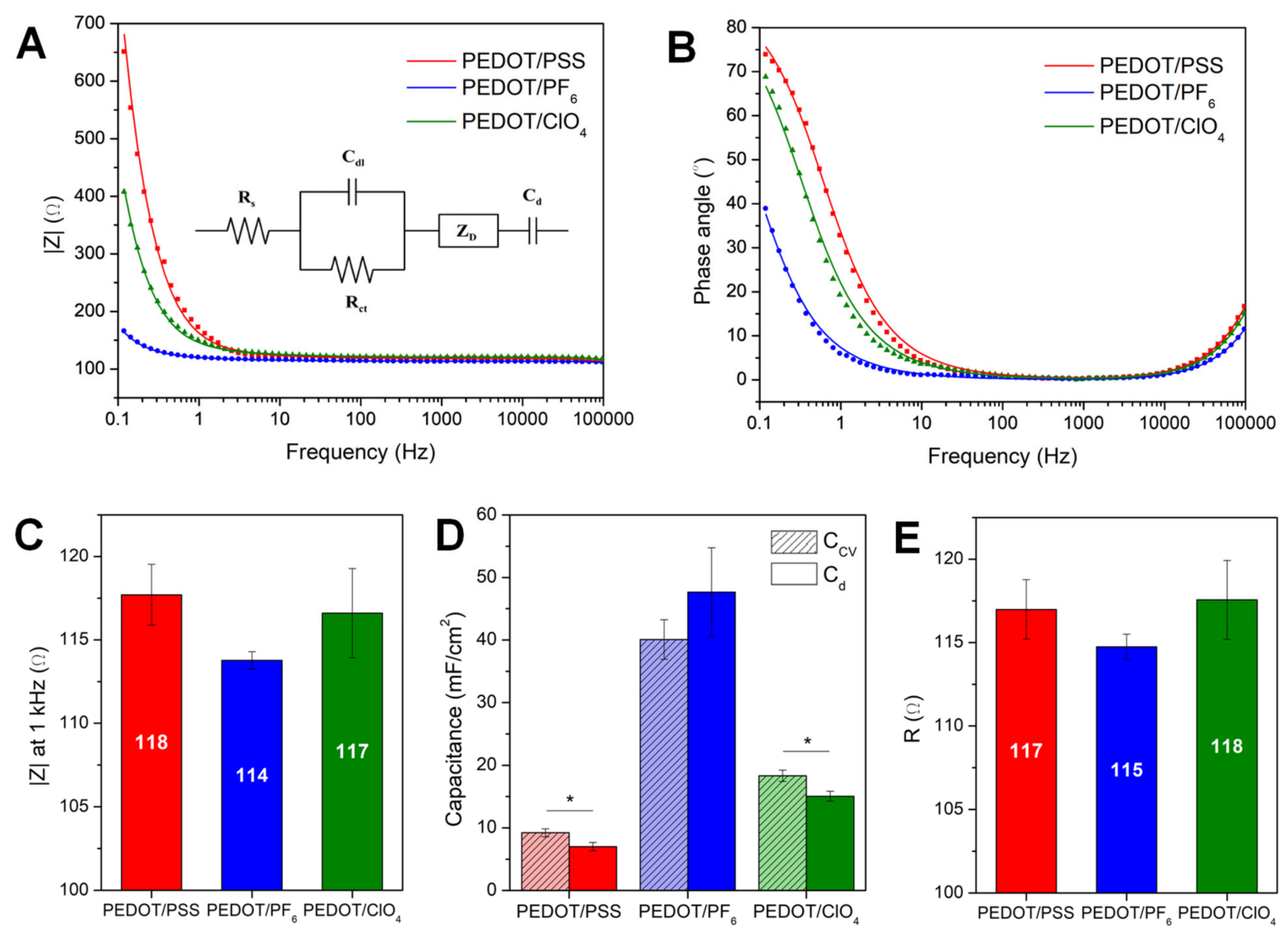

Figure 4. Impedance characterization of PEDOT matrices. EIS data in the form of Bode plots showing the frequencydependent behavior of the (A) impedance modulus and (B) phase angle of platinum electrodes coated with PEDOT/PSS, $\mathrm{PEDOT} / \mathrm{PF}_{6}$, and $\mathrm{PEDOT} / \mathrm{ClO}_{4}$; the equivalent circuit is presented as an inset; dots represent experimental data and lines represent simulated results. (C) Magnitude of impedance at $1 \mathrm{kHz},(\mathbf{D})$ comparison between cyclic voltammetry capacitance $\left(\mathrm{C}_{\mathrm{CV}}\right)$ and polymer capacitance obtained from EIS fitting $\left(\mathrm{C}_{\mathrm{d}}\right)$, and $(\mathrm{E})$ total resistance $\mathrm{R}\left(\mathrm{R}_{\mathrm{s}}+\mathrm{R}_{\mathrm{ct}}\right)$ for PEDOT samples doped with $\mathrm{PSS}^{-}, \mathrm{PF}_{6}{ }^{-}$and $\mathrm{ClO}_{4}{ }^{-} ;{ }^{*} p<0.05 ; n=3$.

Critically, the polymerization solvent was found to possess a more pronounced impact on the capacitance at the polymer surface than a dopant, which was associated with a more developed morphology and more surface available for direct contact with the electrolyte. It could be hypothesized that the observed variation in the capacitance of PEDOT-based materials is related to the changes in the conformation of a conducting polymer matrix occurring as a result of doping with ions of different size and structure, in different environments. It is expected that a key role is played by a chain separation. Recent studies have shown that by modulating chain separation in PEDOT, it is possible to change the properties of the polymer. For instance, an incorporation of Nafion into PEDOT:PSS improved power conversion efficiency of polymer solar cells [58], and a simple treatment of PEDOT:PSS by the organic solvent greatly enhanced the thermoelectric power factor of the polymer [59]. Therefore, it is possible that the changes in chain separation could induce the formation of interfacial polarization, similarly as it happens in conducting polymer composites [60].

By the juxtaposition of the capacitance obtained from equivalent circuit fitting with values calculated from CV curves (Figure $4 \mathrm{D}$ ), a good correlation between $\mathrm{C}_{\mathrm{d}}$ and CSC was evident, confirming the correct fitting of EIS data. Because of an inconclusive fitting of the high frequency region, the values of resistance were compared as a sum of $R_{s}$ and $R_{c t}$, presented as $R$, corresponding to the high frequency resistance, and being close to the resistance measured at $1 \mathrm{kHz}$ (Figure $4 \mathrm{E}$ ). It turned out that the resistance of all the polymer coatings in this study was virtually identical, showing that the choice of dopant had a little influence on the polymer resistance while greatly affecting its capacitive properties. 


\subsection{Biological Characterization}

Although PEDOT is generally recognized as a biocompatible material [48], the presence of different dopants could influence its interactions with tissues. Therefore, a standard colorimetric assay (MTT) was used to compare the viability of cells cultured on different PEDOT formulations with the viability of cells cultured on a bare Pt surface and in an empty well (Figure 5A). A rat B35 neuroblastoma cell line was used to assess the biocompatibility of investigated materials, since it is an easily transfected, cultured cell model of central nervous system neurons. After $48 \mathrm{~h}$ of incubation, a reduced percentage of viable cells $(85 \pm 3 \%)$ was noted on a surface of bare platinum, which is generally regarded as a biocompatible material [61]. Interestingly, when the surface of bare Pt was coated with PEDOT $/ \mathrm{ClO}_{4}$, cell viability was slightly improved $(89 \pm 7 \%)$. Even though perchlorates are known to possess the anti-thyrotoxic activity and interfere with iodide uptake [62], it seems that their interactions with a PEDOT matrix were strong enough to prevent their elution in concentrations from being harmful to cells.

A

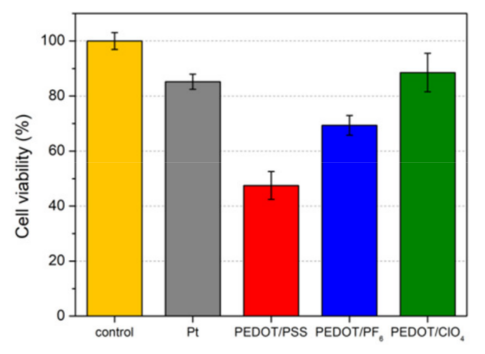

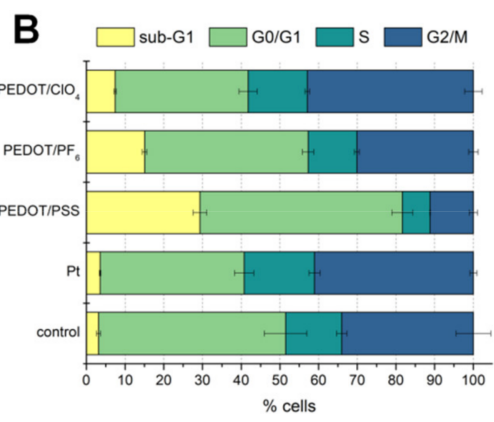

Figure 5. Biological characterization of PEDOT matrices. (A) Cell viability based on an MTT assay; (B) cell cycle distribution; (C) Annexin V and propidium iodide-based apoptosis assay for B35 cells cultured on investigated PEDOT materials, bare Pt electrode and control empty (uncoated) well, for $48 \mathrm{~h}$.

According to the ISO 10993-5:2009 standard [63], a material can be regarded as noncytotoxic when the cell survivability rate exceeds $70 \%$ concerning the control group. Therefore, among three investigated PEDOT formulations, only PEDOT $/ \mathrm{ClO}_{4}$ can be considered biocompatible. The viability of cells cultured on $\mathrm{PEDOT} / \mathrm{PF}_{6}$ was equal to $69 \pm 4 \%$, which placed it at the boundary of biocompatibility, whereas the presence of PEDOT/PSS resulted in the reduction of cellular metabolic activity to $48 \pm 5 \%$, rendering it nonviable. According to previous cytotoxicity studies on doped PEDOT films [15], NaPSS might induce cell inhibition, since it was found to be more toxic than $\mathrm{LiClO}_{4}$ at the concentration of $1 \mathrm{mg} / \mathrm{mL}$.

Apart from cell viability, the choice of a dopant could also affect the cell cycle. Accordingly, the cytometric evaluation of the cell cycle was performed, and the cells were divided into four phases, namely sub- $\mathrm{G}_{1}$ (inactive cells with damaged DNA), $\mathrm{G}_{0} / \mathrm{G}_{1}$ (cells at a resting point), $\mathrm{S}$ (DNA synthesis), and $\mathrm{G}_{2} / \mathrm{M}$ (cells undergoing mitosis) (Figure $5 \mathrm{~B}$ ). For all experimental groups, the largest portion of cells remained in the $G_{0} / G_{1}$ phase. Elevated fraction of B35 cells arrested in this phase, compared to the control group, should be associated with the inhibition of cell development. However, none of the electrode surfaces increased the portion of cells arrested in the $\mathrm{G}_{0} / \mathrm{G}_{1}$ phase, and therefore had no blocking effect on the cellular development [64]. Being responsible for DNA synthesis and mitosis, $\mathrm{S}$ and $\mathrm{G}_{2} / \mathrm{M}$ phases indicate the proliferation of cells. The most significant part of B35 cells remaining in $\mathrm{S}$ and $\mathrm{G}_{2} / \mathrm{M}$ phases was observed for PEDOT/ $\mathrm{ClO}_{4}$ and Pt. Therefore, these surfaces could be considered as supporting cell multiplication. In the case of PEDOT/PSS, a larger percentage of cells was damaged than in the proliferative phases, indicating its destructive effect on the cell culture. This observation was supported by the highest percentage of B35 cells in the sub- $\mathrm{G}_{1}$ phase (29\% for PEDOT/PSS), showing that PEDOT/PSS significantly induced cell death by either apoptosis or necrosis, and this effect was more severe than in the case of PEDOT $/ \mathrm{ClO}_{4}\left(7 \%\right.$ of cells in sub- $\mathrm{G}_{1}$ phase) and 
PEDOT $/ \mathrm{PF}_{6}$ ( $15 \%$ of cells in sub-G $\mathrm{G}_{1}$ phase). Interestingly, the difference between platinum and control sample was insignificant at this stage.

To get a better insight into the origin of cell damage, an apoptosis assay was performed (Figure 5C). The control population was characterized by a high percentage of normal cells (94\%), which proved proper execution of the experiment [65]. Most cell death occurred by necrosis $(6 \%)$, and only less than $1 \%$ entered the physiological apoptosis phase. It is supposed that this cell death distribution might be just a characteristic of this specific cell line, as indicated in a previous study [66]. A high percentage of healthy cells was also noted for PEDOT $/ \mathrm{ClO}_{4}$, with a similar level of necrotic cells as in the control group. Some part of the cells $(9 \%)$ were in the state of early or late apoptosis. Apoptotic death, however, was exceedingly induced on the surface of PEDOT/PF 6 film $(31 \%)$, and this could be a result of the presence of trace amounts of $\mathrm{ACN}$. A similar amount of healthy cells as for PEDOT $/ \mathrm{PF}_{6}(58 \%)$ was noted for PEDOT/PSS (60\%). However, together with a platinum surface, PEDOT/PSS exhibited the highest number of dead cells as a result of necrosis-a pathological, mechanical cell death. It proved them both to be the most deteriorating to cell survivability, even though the cell phase distribution of cells on Pt surface did not indicate such behavior. This discrepancy could result from the high variability of interactions between cells and Pt surface, which made it difficult to accurately predict the response of tissue towards implantable devices.

Apart from supporting the viability of cells, an interface material should also enhance their outgrowth. Therefore, SEM imaging was used to analyze the topography of cells cultured on investigated PEDOT formulations and a Pt control (Figure 6). It was observed that $\mathrm{B} 35$ cells formed a developed, highly branched axon network, particularly on the surface of PEDOT $/ \mathrm{ClO}_{4}$. The cells were found to form the interconnections with a rough polymer layer, confirming that the polymer was well-fitted to the size of cells. In the case of PEDOT $/ \mathrm{PF}_{6}$, the integration of neural cells into the foam-like structure of a polymer matrix was even more pronounced. Due to the corrugated surface of PEDOT interface, the axons intertwined with the polymeric chains. PEDOT/PSS, which was flatter than the other polymers, did not exhibit increased integration with B35 cells. Besides, large clumps of cells were observed on the surface of PEDOT/PSS, which could originate from cell disintegration [67]. Although the smooth surface of platinum provided good adherence of B35 cells, the formation of more sophisticated superficial interactions was not observed.
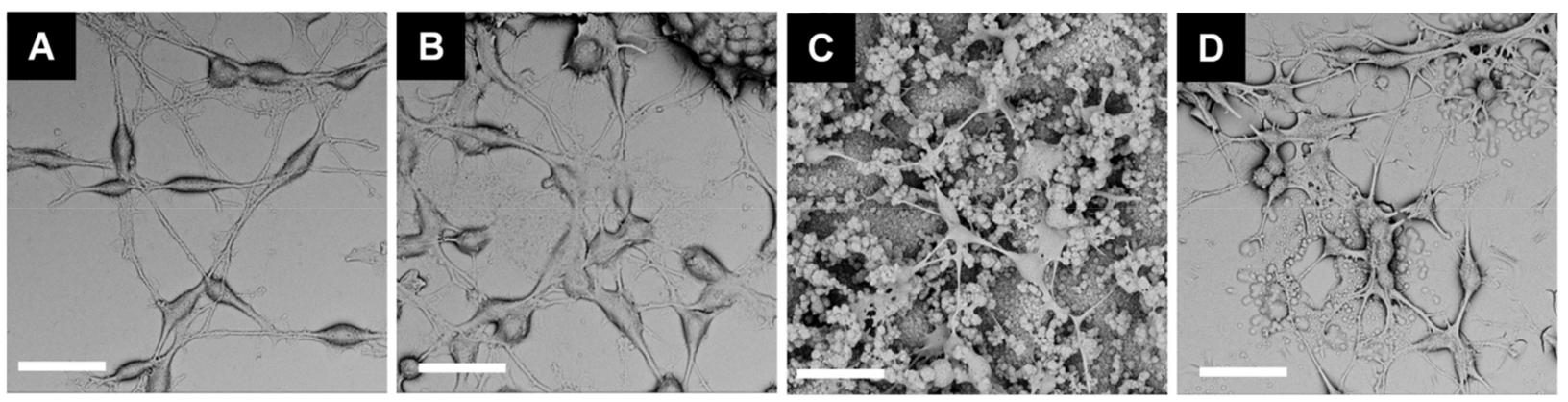

Figure 6. Morphology of B35 cells cultured on PEDOT matrices. SEM micrographs of B35 cells fixed after $48 \mathrm{~h}$ cultured on the surfaces of (A) platinum, (B) PEDOT/PSS, (C) PEDOT/PF , and (D) PEDOT $/ \mathrm{ClO}_{4}$. The scale bar represents $30 \mu \mathrm{m}$.

\section{Conclusions}

In this work, three PEDOT-based materials were fabricated by electrochemical polymerization of EDOT in the presence of different counterions, namely PSS ${ }^{-}$ (poly(styrenesulfonate)), $\mathrm{ClO}_{4}{ }^{-}$(perchlorate), and $\mathrm{PF}_{6}{ }^{-}$(hexafluorophosphate). Despite the common polymeric matrix, the materials varied substantially in terms of capacitive, morphological, and biological properties. Our results not only distinctly demonstrated the powerful impact of a dopant nature on the overall film characteristics, but also served as an incentive for detecting the potential of alternative dopants, other than commonly 
applied PSS, in the design of bioelectronic devices. It was shown that both PEDOT $/ \mathrm{PF}_{6}$ and PEDOT $/ \mathrm{ClO}_{4}$ outperformed PEDOT/PSS in terms of electrical and biological properties. Impressive electrochemical capacitance of $\mathrm{PEDOT} / \mathrm{PF}_{6}$ and superior biocompatibility profile of PEDOT $/ \mathrm{ClO}_{4}$ left behind the results collected for either PEDOT/PSS or a bare platinum electrode. Although PEDOT, and more precisely PEDOT/PSS, is already a well-established player in many research areas including bio-integrated applications, our study restated the applicability of PEDOT in bioelectronics. Eventually, the material endperformance was a synergetic effect of the pivotal nature of PEDOT, modulated by the effect of dopant, and supported by solvent and synthesis parameters selection. Accordingly, we draw attention to doping as a prospective approach that enables fabricating PEDOT substrates with desired functionalities. This strategy could be invaluably facilitated by completing the understanding of the dopant-polymer intertwined relationships. Although our research supplements this knowledge, further studies should be undertaken, taking into account also other alternative counterions. Establishing a library of such assignments would pave the way toward the agile development of conductive platforms imparted with features meticulously tailored to specific interfacing applications.

Author Contributions: Investigation: M.S. (Małgorzata Skorupa), D.W., D.C.-G.; writing-original draft preparation: M.S. (Małgorzata Skorupa), D.W.; visualization: M.S. (Małgorzata Skorupa), D.W.; methodology: M.S. (Magdalena Skonieczna), K.K.; supervision: M.S. (Magdalena Skonieczna), K.K.; writing-review and editing: M.S. (Magdalena Skonieczna); K.K.; conceptualization: K.K.; funding acquisition: K.K. All authors have read and agreed to the published version of the manuscript.

Funding: This research was supported by the National Science Centre, Poland (SONATA 2016/23/ D/ST5/01306 and OPUS 2019/35/B/ST5/00995) and the Silesian University of Technology, Poland (04/040/BK_21/0145, 04/040/BKM21/0178, 04/040/BKM21/0162 and 04/040/RGJ21/0147).

Institutional Review Board Statement: Not applicable.

Informed Consent Statement: Not applicable.

Data Availability Statement: The data presented in this study are available on request from the corresponding author.

Conflicts of Interest: The authors declare no conflict of interest.

\section{References}

1. Solazzo, M.; Krukiewicz, K.; Zhussupbekova, A.; Fleischer, K.; Biggs, M.J.; Monaghan, M.G. PEDOT:PSS interfaces stabilised using a PEGylated crosslinker yield improved conductivity and biocompatibility. J. Mater. Chem. B 2019, 7, 4811-4820. [CrossRef] [PubMed]

2. Higgins, S.G.; Lo Fiego, A.; Patrick, I.; Creamer, A.; Stevens, M.M. Organic Bioelectronics: Using Highly Conjugated Polymers to Interface with Biomolecules, Cells, and Tissues in the Human Body. Adv. Mater. Technol. 2020, 5, 1-35. [CrossRef]

3. ur Rehman, S.; Ahmed, R.; Ma, K.; Xu, S.; Tao, T.; Aslam, M.A.; Amir, M.; Wang, J. Composite of strip-shaped ZIF-67 with polypyrrole: A conductive polymer-MOF electrode system for stable and high specific capacitance. Eng. Sci. 2021, 13, 71-78. [CrossRef]

4. Zhu, Q.; Liu, J.; Wang, X.; Huang, Y.; Ren, Y.; Mu, C.; Liu, X.; Wei, F.; Liu, C. Polypyrrole Functionalized Graphene Oxide Accelerated Zinc Phosphate Coating under Low-Temperature. ES Mater. Manuf. 2020, 9, 48-54. [CrossRef]

5. Mantione, D.; del Agua, I.; Sanchez-Sanchez, A.; Mecerreyes, D. Poly(3,4-ethylenedioxythiophene) (PEDOT) derivatives: Innovative conductive polymers for bioelectronics. Polymers 2017, 9, 354. [CrossRef]

6. Ghasemi-Mobarakeh, L.; Prabhakaran, M.P.; Morshed, M.; Nasr-Esfahani, M.H.; Baharvand, H.; Kiani, S.; Al-Deyab, S.S.; Ramakrishna, S. Application of conductive polymers, scaffolds and electrical stimulation for nerve tissue engineering. J. Tissue Eng. Regen. Med. 2011, 5, e17-e35. [CrossRef]

7. Carli, S.; Bianchi, M.; Zucchini, E.; Di Lauro, M.; Prato, M.; Murgia, M.; Fadiga, L.; Biscarini, F. Electrodeposited PEDOT:Nafion Composite for Neural Recording and Stimulation. Adv. Healthc. Mater. 2019, 8, 1900765. [CrossRef]

8. Fani, N.; Hajinasrollah, M.; Asghari Vostikolaee, M.H.; Baghaban Eslaminejad, M.; Mashhadiabbas, F.; Tongas, N.; Rasoulianboroujeni, M.; Yadegari, A.; Ede, K.F.; Tahriri, M.; et al. Influence of conductive PEDOT:PSS in a hard tissue scaffold: In vitro and in vivo study. J. Bioact. Compat. Polym. 2019, 34, 436-441. [CrossRef]

9. Tadayyon, G.; Krukiewicz, K.; Britton, J.; Larrañaga, A.; Vallejo-Giraldo, C.; Fernandez-Yague, M.; Guo, Y.; Orpella-Aceret, G.; Li, L.; Poudel, A.; et al. In vitro analysis of a physiological strain sensor formulated from a PEDOT:PSS functionalized carbon nanotube-poly(glycerol sebacate urethane) composite. Mater. Sci. Eng. C 2021, 121, 111857. [CrossRef] 
10. Solazzo, M.; Monaghan, M.G. Structural crystallisation of crosslinked 3D PEDOT:PSS anisotropic porous biomaterials to generate highly conductive platforms for tissue engineering applications. Biomater. Sci. 2021. [CrossRef]

11. Popov, A.; Brasiunas, B.; Mikoliunaite, L.; Bagdziunas, G.; Ramanavicius, A.; Ramanaviciene, A. Comparative study of polyaniline (PANI), poly(3,4-ethylenedioxythiophene) (PEDOT) and PANI-PEDOT films electrochemically deposited on transparent indium thin oxide based electrodes. Polymer 2019, 172, 133-141. [CrossRef]

12. Popov, A.; Brasiunas, B.; Damaskaite, A.; Plikusiene, I.; Ramanavicius, A.; Ramanaviciene, A. Electrodeposited gold nanostructures for the enhancement of electrochromic properties of pani-pedot film deposited on transparent electrode. Polymers 2020, 12, 2778. [CrossRef] [PubMed]

13. Guimard, N.K.; Gomez, N.; Schmidt, C.E. Conducting polymers in biomedical engineering. Prog. Polym. Sci. 2007, 32, 876-921. [CrossRef]

14. Ravichandran, R.; Sundarrajan, S.; Venugopal, J.R.; Mukherjee, S.; Ramakrishna, S. Applications of conducting polymers and their issues in biomedical engineering. J. R. Soc. Interface 2010, 7, 559-579. [CrossRef] [PubMed]

15. Baek, S.; Green, R.A.; Poole-Warren, L.A. Effects of dopants on the biomechanical properties of conducting polymer films on platinum electrodes. J. Biomed. Mater. Res. Part A 2014, 102, 2743-2754. [CrossRef] [PubMed]

16. del Valle, M.A.; Ramírez, A.M.; Hernández, L.A.; Armijo, F.; Díaz, F.R.; Arteaga, G.C. Influence of the supporting electrolyte on the electrochemical polymerization of 3,4-ethylenedioxythiophene. effect on p- and n-Doping/Undoping, Conductivity And Morphology. Int. J. Electrochem. Sci. 2016, 11, 7048-7065. [CrossRef]

17. Cysewska, K.; Karczewski, J.; Jasiński, P. Influence of electropolymerization conditions on the morphological and electrical properties of PEDOT film. Electrochim. Acta 2015, 176, 156-161. [CrossRef]

18. Bondarenko, A.S.; Ragoisha, G.A. EIS Spectrum Analyser. In Progress in Chemometrics Research; Nova Science: New York, NY, USA, 2005; pp. 89-102. ISBN 1594542570.

19. Krukiewicz, K.; Kruk, A.; Turczyn, R. Evaluation of drug loading capacity and release characteristics of PEDOT/naproxen system: Effect of doping ions. Electrochim. Acta 2018, 289, 218-227. [CrossRef]

20. Krukiewicz, K.; Zak, J.K. Conjugated polymers as robust carriers for controlled delivery of anti-inflammatory drugs. J. Mater. Sci. 2014, 49, 5738-5745. [CrossRef]

21. Krukiewicz, K.; Kowalik, A.; Czerwińska-Główka, D.; Biggs, M. Electrodeposited poly(3,4-ethylenedioxypyrrole) films as neural interfaces: Cytocompatibility and electrochemical studies. Electrochim. Acta 2019, 302, 21-30. [CrossRef]

22. Han, D.H.; Lee, H.J.; Park, S.M. Electrochemistry of conductive polymers XXXV: Electrical and morphological characteristics of polypyrrole films prepared in aqueous media studied by current sensing atomic force microscopy. Electrochim. Acta 2005, 50, 3085-3092. [CrossRef]

23. Bodart, C.; Rossetti, N.; Hagler, J.; Chevreau, P.; Chhin, D.; Soavi, F.; Schougaard, S.B.; Amzica, F.; Cicoira, F. Electropolymerized Poly(3,4-ethylenedioxythiophene) (PEDOT) Coatings for Implantable Deep-Brain-Stimulating Microelectrodes. ACS Appl. Mater. Interfaces 2019, 11, 17226-17233. [CrossRef]

24. Vernitskaya, T.V.; Efimov, O.N. Polypyrrole: A conducting polymer (synthesis, properties, and applications). Usp. Khim. 1997, 66, 502-505. [CrossRef]

25. Seki, Y.; Takahashi, M.; Takashiri, M. Effects of different electrolytes and film thicknesses on structural and thermoelectric properties of electropolymerized poly(3,4-ethylenedioxythiophene) films. RSC Adv. 2019, 9, 15957-15965. [CrossRef]

26. Poverenov, E.; Li, M.; Bitler, A.; Bendikov, M. Major effect of electropolymerization solvent on morphology and electrochromic properties of PEDOT films. Chem. Mater. 2010, 22, 4019-4025. [CrossRef]

27. Łapkowski, M.; Pron, A. Electrochemical oxidation of poly(3,4-ethylenedioxythiophene) - 'in situ' conductivity and spectroscopic investigations. Synth. Met. 2000, 110, 79-83. [CrossRef]

28. Friis, E.P.; Andersen, J.E.T.; Madsen, L.L.; Bonander, N.; Moller, P.; Ulstrup, J. Dynamics of pseudomonas aeruginosa azurin and its Cys3Ser mutant at single-crystal gold surfaces investigated by cyclic voltammetry and atomic force microscopy. Electrochim. Acta 1998, 43, 1114-1122. [CrossRef]

29. Krische, B.; Zagorska, M. Overoxidation in conducting polymers. Synth. Met. 1989, 28, 257-262. [CrossRef]

30. Tamburri, E.; Orlanducci, S.; Toschi, F.; Terranova, M.L.; Passeri, D. Growth mechanisms, morphology, and electroactivity of PEDOT layers produced by electrochemical routes in aqueous medium. Synth. Met. 2009, 159, 406-414. [CrossRef]

31. Zykwinska, A.; Domagala, W.; Pilawa, B.; Lapkowski, M. Electrochemical overoxidation of poly(3,4-ethylenedioxythiophene)PEDOT studied by means of in situ ESR spectroelectrochemistry. Electrochim. Acta 2005, 50, 1625-1633. [CrossRef]

32. Jayakumar, C.; Reddy, Y.S.; Kulandainathan, M.A.; Jeyaraj, B. Fabrication of PEDOT-PSS modified glassy carbon electrode for Biosensor and its performance in determining L-dopa in the presence of Ascorbic acid. J. Chem. Pharm. Res. 2016, 8, 512-520.

33. Aurian-Blajeni, B. Correlation Between Charge Storage Capacity and Morphology. J. Electrochem. Soc. 1987, 134, 2637. [CrossRef]

34. Culebras, M.; Gómez, C.M.; Cantarero, A. Enhanced thermoelectric performance of PEDOT with different counter-ions optimized by chemical reduction. J. Mater. Chem. A 2014, 2, 10109-10115. [CrossRef]

35. Xia, J.; Masaki, N.; Jiang, K.; Yanagida, S. The influence of doping ions on poly(3,4-ethylenedioxythiophene) as a counter electrode of a dye-sensitized solar cell. J. Mater. Chem. 2007, 17, 2845-2850. [CrossRef]

36. Simoes, M.C.; Hughes, K.J.; Ingham, D.B.; Ma, L.; Pourkashanian, M. Estimation of the Thermochemical Radii and Ionic Volumes of Complex Ions. Inorg. Chem. 2017, 56, 7566-7573. [CrossRef] 
37. Agrawal, V.; Shahjad; Bhardwaj, D.; Bhargav, R.; Sharma, G.D.; Bhardwaj, R.K.; Patra, A.; Chand, S. Morphology and Doping Level of Electropolymerized Biselenophene-Flanked 3,4- Ethylenedioxythiophene Polymer: Effect of Solvents and Electrolytes. Electrochim. Acta 2016, 192, 52-60. [CrossRef]

38. del Valle, L.J.; Aradilla, D.; Oliver, R.; Sepulcre, F.; Gamez, A.; Armelin, E.; Alemán, C.; Estrany, F. Cellular adhesion and proliferation on poly(3,4-ethylenedioxythiophene): Benefits in the electroactivity of the conducting polymer. Eur. Polym. J. 2007, 43, 2342-2349. [CrossRef]

39. Boyd, R.D.; Verran, J.; Jones, M.V.; Bhakoo, M. Use of the atomic force microscope to determine the effect of substratum surface topography on bacterial adhesion. Langmuir 2002, 18, 2343-2346. [CrossRef]

40. Hsu, L.C.; Fang, J.; Borca-Tasciuc, D.A.; Worobo, R.W.; Moraru, C.I. Effect of micro- and nanoscale topography on the adhesion of bacterial cells to solid surfaces. Appl. Environ. Microbiol. 2013, 79, 2703-2712. [CrossRef]

41. Bear, M.F.; Connors, B.W.; Paradiso, M.A. Neuroscience: Exploring the Brain, 4th ed.; Lippincott Williams Wilkins: Philadelphia, PA, USA, 2015; ISBN 9781496317001.

42. Garreau, S.; Duvail, J.L.; Louarn, G. Spectroelectrochemical studies of poly(3,4-ethylenedioxythiophene) in aqueous medium. Synth. Met. 2001, 125, 325-329. [CrossRef]

43. Chiu, W.W.; Travaš-Sejdić, J.; Cooney, R.P.; Bowmaker, G.A. Studies of dopant effects in poly(3,4-ethylenedioxythiophene) using Raman spectroscopy. J. Raman Spectrosc. 2006, 37, 1354-1361. [CrossRef]

44. Cogan, S.F. Neural Stimulation and Recording Electrodes. Annu. Rev. Biomed. Eng. 2008, 10, 275-309. [CrossRef]

45. Du, Z.J.; Luo, X.; Weaver, C.L.; Cui, X.T. Poly(3,4-ethylenedioxythiophene)-ionic liquid coating improves neural recording and stimulation functionality of MEAs. J. Mater. Chem. C 2015, 3, 6515-6524. [CrossRef] [PubMed]

46. King, Z.A.; Shaw, C.M.; Spanninga, S.A.; Martin, D.C. Structural, chemical and electrochemical characterization of poly(3,4Ethylenedioxythiophene) (PEDOT) prepared with various counter-ions and heat treatments. Polymer 2011, 52, 1302-1308. [CrossRef]

47. Starbird, R.; Bauhofer, W.; Meza-Cuevas, M.; Krautschneider, W.H. Effect of experimental factors on the properties of PEDOTNaPSS galvanostatically deposited from an aqueous micellar media for invasive electrodes. In The 5th 2012 Biomedical Engineering International Conference; IEEE: New York, NY, USA, 2012; pp. 1-5.

48. Boehler, C.; Aqrawe, Z.; Asplund, M. Applications of PEDOT in bioelectronic medicine. Bioelectron. Med. 2019, 2, 89-99. [CrossRef]

49. Rauti, R.; Musto, M.; Bosi, S.; Prato, M.; Ballerini, L. Properties and behavior of carbon nanomaterials when interfacing neuronal cells: How far have we come? Carbon 2019, 143, 430-446. [CrossRef]

50. Cui, X.; Martin, D.C. Electrochemical deposition and characterization of poly(3,4-ethylenedioxythiophene) on neural microelectrode arrays. Sens. Actuators B Chem. 2003, 89, 92-102. [CrossRef]

51. Abidian, M.R.; Martin, D.C. Multifunctional nanobiomaterials for neural interfaces. Adv. Funct. Mater. 2009, 19, 573-585. [CrossRef]

52. Danielsson, P.; Bobacka, J.; Ivaska, A. Electrochemical synthesis and characterization of poly(3,4- ethylenedioxythiophene) in ionic liquids with bulky organic anions. J. Solid State Electrochem. 2004, 8, 809-817. [CrossRef]

53. Kim, R.; Nam, Y. Polydopamine-doped conductive polymer microelectrodes for neural recording and stimulation. J. Neurosci. Methods 2019, 326, 108369. [CrossRef]

54. Higgins, T.M.; Coleman, J.N. Avoiding Resistance Limitations in High-Performance Transparent Supercapacitor Electrodes Based on Large-Area, High-Conductivity PEDOT:PSS Films. ACS Appl. Mater. Interfaces 2015, 7, 16495-16506. [CrossRef]

55. Bianchi, M.; Carli, S.; Di Lauro, M.; Prato, M.; Murgia, M.; Fadiga, L.; Biscarini, F. Scaling of capacitance of PEDOT:PSS: Volume: Vs. area. J. Mater. Chem. C 2020, 8, 11252-11262. [CrossRef]

56. Deokate, R.J. Chemically Deposited $\mathrm{NiCO}_{2} \mathrm{O}_{4}$ Thin Films for Electrochemical Study. ES Mater. Manuf. 2020. [CrossRef]

57. Patil, S.S.; Bhat, T.S.; Teli, A.M.; Beknalkar, S.A.; Dhavale, S.B.; Faras, M.M.; Karanjkar, M.M.; Patil, P.S. Hybrid Solid State Supercapacitors (HSSC's) for High Energy \& Power Density: An Overview. Eng. Sci. 2020, 12, 38-51. [CrossRef]

58. Hou, X.; Li, Q.; Cheng, T.; Yu, L.; Wang, F.; Lin, J.; Dai, S.; Li, Y.; Tan, Z. Improvement of the power conversion efficiency and long term stability of polymer solar cells by incorporation of amphiphilic Nafion doped PEDOT-PSS as a hole extraction layer. J. Mater. Chem. A 2015, 3, 18727-18734. [CrossRef]

59. Bharti, M.; Singh, A.; Samanta, S.; Debnath, A.K.; Marumoto, K.; Aswal, D.K.; Muthe, K.P.; Gadkari, S.C. Elucidating the mechanisms behind thermoelectric power factor enhancement of poly(3,4-ethylenedioxythiophene):poly(styrenesulfonate) flexible films. Vacuum 2018, 153, 238-247. [CrossRef]

60. Chen, C.H.; Kine, A.; Nelson, R.D.; LaRue, J.C. Impedance spectroscopy study of conducting polymer blends of PEDOT:PSS and PVA. Synth. Met. 2015, 206, 106-114. [CrossRef]

61. Czerwińska-Główka, D.; Przystaś, W.; Zabłocka-Godlewska, E.; Student, S.; Cwalina, B.; Łapkowski, M.; Krukiewicz, K. Bacterial Surface Colonization of Sputter-Coated Platinum Films. Materials 2020, 13, 2674. [CrossRef] [PubMed]

62. Sijimol, M.R.; Jyothy, S.; Pradeepkumar, A.P.; Chandran, M.S.S.; Ghouse, S.S.; Mohan, M. Review on Fate, Toxicity, and Remediation of Perchlorate. Environ. Forensics 2015, 16, 125-134. [CrossRef]

63. International Organization for Standardization. Biological Evaluation of Medical Devices_Part 5: Tests for in vitro Cytotoxicity; International Organization for Standardization: Geneva, Switzerland, 2009. 
64. Altmann, S.; Choroba, K.; Skonieczna, M.; Zygadło, D.; Raczyńska-Szajgin, M.; Maroń, A.; Małecki, J.G.; Szłapa-Kula, A.; Tomczyk, M.; Ratuszna, A.; et al. Platinum(II) coordination compounds with $4^{\prime}$-pyridyl functionalized 2,2':6', $2^{\prime \prime}$-terpyridines as an alternative to enhanced chemotherapy efficacy and reduced side-effects. J. Inorg. Biochem. 2019, 201, 110809. [CrossRef] [PubMed]

65. Skierski, J. Badanie działania cytotoksycznego substancji chemicznych. Postępy Biol. Komórki. Supl. 2008, 24, 147-163.

66. Odrobińska, J.; Skonieczna, M.; Neugebauer, D. Micellar carriers of active substances based on amphiphilic PEG/PDMS heterograft copolymers: Synthesis and biological evaluation of safe use on skin. Int. J. Mol. Sci. 2021, 22, 1202. [CrossRef] [PubMed]

67. Linnemans, W.A.M.; Wiersema, P.H.; Spies, F.; Elbers, P.F. A kinetic model for cell agglutination. Exp. Cell Res. 1976, 101, 184-190. [CrossRef] 